subject, the Virus Research Centre has served as a contre for research and training in virology and has given facilities to many workers, both Indian and foreign, for acquiring practical knowledgo in the techniques of virology.

During the decade of its existonce, the Virus Research Centre has carried out a large number of investigations, among them being: (1) serological surveys for arboviruses in several parts of India; (2) 'Jamshedpur fever' and a similar disease (the so-called 'mystery disease') prevailing in several cities of North India in the year 1953-54 and subsequent outbreaks of encephalitis in Nagpur, Delhi and other places; (3) Japanese encephalitis and its related problems in Madras, Andhra, Pradesh and Mysore States; (4) Kyasanur Forest disease, a new tick-borne virus disease of man and monkeys in the forests of Mysore State, and its possible occurrence in other parts of India; (5) the epidemiology of dengue fever in Madras State and the recognition of the occurrence of dengue type 4 in
India; (6) the outbreak of African horse sickness for the first time in the Indian sub-continent in the year 1960 ; (7) the outbreak of infectious hepatitis in Dolhi; (8) laboratory and field studies on mosquitoes, particularly in Poona district and in South India; (9) tho taxonomy and bohaviour of Indian species of ticks; and (10) the avian and mammalian fauna of India and their potentialities as disseminators of virus diseases.

The Centre has undertaken several investigations on viruses other than arboviruses, such as rabies, Newcast le disease (Ranikhet), herpes, Coxsackie and other enteroviruses. The impetus given to medical zoology including modical entomology has been significant. Full details of the work of the Centre are described in its annual report for $1962 \ddagger$. $\ddagger$ Indian Council of Medical Research, New Delhi. 1962 Annual Report
of the Virus Research Centre, Poona. Pp. iv $+114+1$ plate. (New Delhi: of the Virus Research Centre, Poona. Pp.
Indian Council of Medical Research, 1963.)

\title{
TOXIC CHEMICALS IN AGRICULTURE AND FOOD STORAGE
}

$\mathrm{T}$ HE report of the Research Committee on Toxic Chemicals*, which was set up at the request of the Minister for Science by the Agricultural Research Council, under the chairmanship of Prof. A. C. Frazer, does not point to any major gaps in research on pest-control products at the present time, but recommends that certain aspects of research should be strengthened. The report is a sequel to the report in September 1961 of a Research Study Group on Toxic Chemicals used in Agriculture and Food Storage, of which Dr. (now Sir Harold) Sanders was chairman. The Committee was to review research carried out under the auspices of the four Research Councils on the effects of toxic chemicals used in agriculture and food storage and to make recommendations for future research. It appointed working parties to consider particular aspects such as ecological studies, plant breeding, biological control and other alternative methods which might reduce risks to wild animals and plants. These subjects are discussed in the first sections of the report, following which the main research problems are considered under eight headings: the assessment of hazards arising from the use of pestcontrol products; development of methods of pest control; development of new products; control of potential hazards; co-ordination of effort; man-power; further research needs; and priorities.

Work is already proceeding on all the problems discussed, and a useful feature of the report is the appended summary of work in progress. Further work, however, is urgently needed on the behaviour and accumulation of pest-control products in soil and water and their effects on soil organisms and on aquatic flora and fauna, as well as on the possibility of breeding for resistance to important insect pests in crops where no satisfactory control is known, or where the present chemical methods are unsatisfactory. Further ecological investigations on whole populations of pests and other species are required to provide essential background information, and here it is suggested university departments of botany and zoology might contribute. It is also doubtful whether research into the exploitation of diseases of insects as a method of control is adequate. The Committee suggests that there is a case for establishing an insect pathology laboratory, concentrating in the first place on bacterial and virus diseases of insects. Support of the fundamental work required for the more effective use of sterilants, attractants and repellants for control purposes is urged, as well as toxicological investigations to relate the levels of pesti-

* Agricultural Research Council. Report of the Research Committee on Toxic Chemicals. Pp. iv +38 . (London: Agricultural Research Council A vailable from H.M.S.O., 1964.) $2 s$. $6 d$. cides found in tissues of birds and mammals and possible toxic effects. This would supplement the information from ecological examinations, but continued support is required for investigations on the biochemistry and toxicology of pest-control products. This is fundamental to the interpretation of data obtained by analytical surveys, the discovery of new products to control resistance, or the development of safer, more selective and less-resistant products, as well as to the discovery of diagnostic tests of exposure to or poisoning by such products, and the successful treatment of those who may be poisoned. Attention should also be directed to the development of quantitative methods of analysis suitable for use by public analysts and others, and here a central source of information is needed. Further effort is required on work that may lead to the development of safer, more selective and less persistent products, while if it is decided to establish a monitoring service as part of the control organization those concerned with research should be kept fully informed of the results.

Most of these recommendations are directed specifically to the attention of the Agricultural Research Council. The Committee also recommends that the attention of the Medical Research Council should be directed to the need for: (1) evaluating the toxicological significance of the presence of these products in human tissues; (2) continuing support and development of toxicological and biochemical investigations on pest-control products in mammals; (3) ensuring that every suspected case of such poisoning in man is fully investigated and the information obtained made known to the Research Committee. The Department of Scientific and Industrial Research should note the need for establishing a central source of information on the chemistry and analysis of these products and their residues (for which purpose the Laboratory of the Government Chemist is suggested as being appropriate) and for research investigations on the development of analytical methods necessary and suitable for a monitoring system if this is considered desirable. The Nature Conservancy should consider the need for further ecological investigations on whole populations of chosen species, and for examining the practicability of controlling a land area of 1,000 acres in such a way as to permit quantitative investigations of the effects of pestcontrol products on wild-bird population. Moreover, co-operation is required, for example, with river boards and Government departments concerned with water resources, in examining contamination of fresh water by chemical products, in studying the accumulation of such products in animals, and in studying the faunal and floral changes in inland waters. 
Other recommendations were addressed to the attention of all the Research Councils. These are the need, first for further support for work leading to the development of more selective and safer products of limited persistenco-a recommendation to which high priority is attached; secondly, for occasional meetings to correlate analytical findings, for passing on information on these detailed research needs to appropriate research departments, including those in universities; and thirdly, for toxicological and biological investigations in birds and wild-life generally. High priority is also recommended for the more extensive ecological investigations, the improvement of methods for such investigations, the assessment of the prevent level of contamination of the environment by pest-control products, and of the toxicological significance to man and wild-life, as well as to more research on biological control methods. In sum, it amounts to considerable research effort, which, as the Committer recognizes, makes a demand for trained man-power in categories where the shortage often appears to be worldwide. To meet that demand, and to provide the necessary resources of equipment and finance is, however, the urgent and inescapable price now to be paid for shortsightedness in the past.

\section{GEOLOGY IN SCHOOLS}

\begin{abstract}
WO recent presidential addresses, to the Geological Society of London and Geologists' Association, respectively, have laid stress on public onlightenment in Earth sciences and how this may be accomplished. Ono of the obvious, but long-term policies. in creating an enlightened lay public is to introduco tho subject into schools at all levels, from primary to secondary. As a first step towards this, a course for actual and prospective teachers of geology was hold at Queen Mary College during March 23-25. This was almost certainly the first course of its typo to be held in Britain. Nearly forty peoplo attended, drawn from a wide range of schools. For two days various aspocts of the teaching of stratigraphy, palacontology, petrology and mineralogy were discussed at length. Other subjects included teaching aids and the practical probloms of the school geology teacher. The coverage of the relevant branches of the subject was completed by a demonstration field excursion to the south of London.

Several significant pointers for the future omerged from the discussions. One of these was that the advances made in the subject were such as to make a sound background in chemistry and mathematics essential for successful teaching, especially at advanced level of the General Certificate of Education (G.C.E.). As many teacher's have. in fact, an arts background they may well be progressivoly winnowed out by modernization of
\end{abstract}

syllabi. This is clearly undesirable. espocially in view of the fact that many prosent-day G.C.E. syllabi need drastic ro-thinking. Hence, if geology is to maintain and strengthen its place in British schools more provision must be made for revision courses by university departments. Otherwise, the only alternatives for many experienced teachers will be to teach the subjoct to a lower standard (O-level or Certificate of Sncondary Education) or cease to teach it at all.

Despite the fact that examination syllabi fragment the scienco and fragment its teaching, emphasis in the course was laid on unifying the various branches as frequently as possible. 'This is most readily accomplished in natural history subjects by field studies, and sorne education authorities are now becoming aware of the need to budget for school field activitios. As field classes become more commonplace. however, it follows that there must be more centres capable of accommodating school groups. Otherwise the expansion of geology in schools may be hondicapped.

The liaison effected betweon the teachers, lecturers and examiners attending the course was undoubtedly beneficial and a healthy sign in the revitalization of a subject which tends to be underrated, culturally and academically, by most schools, public media of communication. and the lay public alike.

\section{ORES AND METALS}

\begin{abstract}
A RECEN'T report from the Ancient Mining and Metallurgy Committee of the Royal Anthropological Instituto, Ores and Metals*, consists of throe sections: "A Note on Irish Copper Ores and Metals", by Mr. H. H. Coghlan; "Elemonts in Irish Copper Ores", by Dr. J. R. Butler; and finally, "A Metallurgical Study of Four Bronze-Age Implements", by Dr. George Parker. An onormous amount of data concerned with a restricted area, some previously published and some now, has been brought together dealing with the sources available and the metal (presumably) produced from them. The whole work is, as the main author says, "very much in the nature of a preliminary investigation" and as such is to be whole-heartedly welcomed. Dr. Butler's share has been the task of analysing some hundred samples of the ores and is a contribution of outstanding importance. Dr. Parker provides a detailed metallurgical examination of five spocimens, including the rivets of a halberd. of Bronze Age implements. Such work is of fundamental importance and more is needed. One of the points of special intorest in this report is that, again including the

* Ores and Metals: a Report of the Ancient Mining and Metallurgy Committee, Royal Anthrepological Institute. (Royzl Anthropological Institut Occasional Paper, No. 17.) By H. H. Coghlan, J. R. Butler and Georgo Britain and Irelaud, 1963.) 358 .
\end{abstract}

rivets. only two are in bronzos, the remaindor being copper. Such ovidence that then, as now, different types of metal were in use at one and the same time is well worth bearing in mind.

The largest section, in which the results are considered. is dirocted to the hope that from a detailed investigation of the impurities in the motal and in the ore it will in the end be possible to rolate the two and thus, wherever it be found, discover the place of origin of the metal. As is very properly pointed out, this can only be done for those times, if such in fact do exist, before scrup metals from different sources were melted together. To a metallurgist it would appear that the uncertainties involved in the ore-metal correlation have been undorestimated. Among other things, for example, ores do vary, sornetimes greatly, with depth both for geological reusons and as a result of weathering. It is stated in the report thet "the. prohistorie miner usually worked by open-ceust, and but a few feet below the surface". Though doubtloss true in the oarliest days, ovidence of mining by 'fire-setting' as carly as the second millenium B.C. shows that oven then unweathored ore was being won. The further implication that not until the Roman poriod was ore worked which might vary in composition from that of tho woathered surfaco material is exceedingly difficult to accept whon it is 